\title{
Do Low-Income Families Benefit from Minimum Wage Increases? Evidence from State-Level Minimum Wage Laws
}

\author{
Mark D. Partridge and Jamie S. Partridge*
}

\begin{abstract}
Several recent studies contend that falling real minimum wage rates are an important factor behind rising wage inequality and increasing poverty rates. Other studies find the more conventional result that they have very little influence on poverty and inequality, but these studies are generally based on simulated labor market responses. This study examines the influence of minimum wage rates on poverty rates and family income inequality using state-level minimum wages. The methodology has the key advantage of not requiring simulated labor market responses to minimum wage increases. The results suggest that increases in minimum wage rates and coverage do not reduce poverty rates or income inequality.
\end{abstract}

\section{INTRODUCTION}

Raising the minimum wage has traditionally been viewed by many policy makers as one way to reduce poverty and to provide a "living wage" to workers at the bottom of the income ladder (Gramlich 1976; Freeman 1996; Kuttner 1997). With inflation eroding the purchasing power of a fixed minimum wage, every few years there are calls to increase state and federal minimum wage rates, which keeps the minimum wage issue at the forefront of U.S. policy discussion. For example, even before the U.S. federal minimum wage was increased to $\$ 5.15$ an hour in September 1997, there were already proposals to raise it to over $\$ 7.00$ an hour (Reynolds 1997).

Most minimum wage studies (at least in the U.S.) have examined its influence on employment. Yet there has been much less research regarding the ultimate policy goal of minimum wage policies-raising the living standards of low-income workers and families. For example, the declining value of the real minimum wage during the 1980s has been identified as possibly causing about 30 percent of the ensuing increase in U.S. wage inequality for individual workers, where similar outcomes have been found for Canada and the United Kingdom (Card and Krueger 1995; DiNardo, Fortin, and Lemieux 1996; DiNardo and Lemieux 1997; Machin and Manning 1994). However, there is much less evidence that raising the minimum wage can reduce family income inequality or reduce poverty rates. One study that examines this issue is that of Card and Krueger (1995), who found evidence that the 1990-91 federal minimum wage hike reduced U.S. family income inequality and modestly reduced poverty rates. However,

*Assistant Professor, Department of Economics, St. Cloud State University, St. Cloud, MN, and Assistant Professor, Department of Management, St. John's University/College of St. Benedict, St. Joseph, MN. The authors thank Dan Rickman for his help with this study. 
others argue that minimum wage policies have virtually no effect on poverty rates or on family income inequality (e.g., Even and Macpherson 1996; Horrigan and Mincy 1993).

Given that the ultimate goal of minimum wage rules is to improve the welfare of low-income families and to reduce poverty, these conflicting findings provide little guidance to policy makers. In particular, policy makers need better estimates to help assess the relative benefits of various anti-poverty programs, which also include job training and earned income tax credits. Moreover, the federal devolution of welfare programs to U.S. states signifies that more research should be done at the state level, where anti-poverty efforts will be increasingly concentrated. Therefore, this study will examine the effects of state-level minimum wage laws on U.S. poverty rates and on family income inequality. Comparing differences between states that had a minimum wage rate above the federal rate to states that did not produces a unique natural experiment with a credible counterfactual (Card and Krueger 1995). In particular, this methodology has important advantages over previous studies that simulate the impact of minimum wage rates on income distribution. For example, there is no need for estimates of employment responses by firms or labor supply decisions by other family members.

In what follows, section II outlines the relevant minimum wage literature and discusses some advantages of the current study's methodology. Section III discusses the empirical implementation and section IV discusses the results. The final section presents some concluding thoughts.

\section{PREVIOUS LITERATURE}

The goal of many advocates of minimum wage hikes is to provide a "living wage" along with a desire to "make work pay." Yet many economists have cautioned that raising the minimum wage has deleterious consequences, including employment losses, reduced general training, and offsetting reductions in fringe benefits. ${ }^{1}$ In particular, conventional arguments suggest that employment losses and other losses should be concentrated among the less-skilled (e.g., teens and minorities), the very workers the minimum wage is presumed to benefit (e.g., see Brown, Gilroy, and Kohen's (1982) literature review).

Conclusions from more recent minimum wage studies have been more optimistic. For example, Card (1992) and Card and Krueger (1995) found little evidence that federal minimum wage increases in 1990 and 1991 reduced employment. ${ }^{2}$ These studies are noteworthy because if there are few negative employment consequences of raising the minimum wage, then minimum wage increases should reduce poverty rates to some degree and would likely reduce family income inequality as well. ${ }^{3}$

\footnotetext{
${ }^{1} \mathrm{~A}$ theoretical model of the impact of minimum wage rates on the labor market and on the income distribution can be found in Gramlich (1976).

${ }^{2}$ Machin and Manning (1994) found similar results for the United Kingdom. However, findings that minimum wage increases do not reduce employment have not gone unchallenged (e.g., Deere, Murphy, and Welch 1995; Neumark and Wascher 1992; Partridge and Partridge forthcoming; Williams 1993).

${ }^{3}$ As Freeman (1996) notes, if the employment elasticity is less than one for low-income workers, raising the minimum wage would increase the total aggregate income going to these workers.
} 
Somewhat consistent with this point, several studies have found that raising the minimum wage reduces wage inequality (e.g., DiNardo, Fortin, and Lemieux 1996). However, reducing wage inequality does not necessarily mean reductions in family income inequality or poverty rates if minimum wage earners are distributed somewhat uniformly throughout the income distribution. Likewise, a higher minimum wage may induce a positive labor supply response from middleincome spouses or children that can displace low-income workers (Freeman 1996).4 Nonetheless, using a "natural experiment" approach, Card and Krueger (1995) concluded that states with a greater share of workers affected by the 1990-91 federal minimum wage increase had greater reductions in family income inequality and (likely) lower poverty rates. Also, Machin and Manning (1996) drew similar conclusions for the U.K. Yet other studies contradict Card and Krueger's findings. For example, Burkhauser, Couch, and Wittenburg (1996), Even and Macpherson (1996), and Sloane and Theodossiou (1996) argue that minimum wage earners are too spread across the income distribution to have any meaningful influence on poverty rates or family income inequality. ${ }^{5}$ In fact, Burkhauser, Couch, and Wittenburg (1996) found that only 19 percent of the increased earnings from the 1990-91 federal minimum wage hike went to poor families.

One problem with studies that find that the minimum wage has little influence on poverty rates or on the family income distribution is that they typically simulate labor market responses. These studies generally assume a base employment elasticity with respect to the minimum wage, which can greatly influence the results. Likewise, they usually ignore ripple effects when minimum wage hikes induce firms to raise wages for workers who already earned above the new minimum wage, perhaps because the firm wants to maintain its current wage distribution (Card and Krueger 1995). Such a ripple effect can reduce poverty rates. Other factors that are also typically ignored include firm noncompliance, compensating reductions in welfare benefits, reallocations between full- and part-time work, and any offsetting labor supply changes by family members. These latter responses tend to offset any favorable impacts on poverty rates and family income inequality. Finally, the interaction between the covered and uncovered sectors is either ignored or estimated.

The complex labor market responses that simulations either estimate or disregard imply that Card and Krueger's (1995) "natural experiment" method has significant advantages. Nonetheless, Card and Krueger (1995) only utilized 51 state observations in their analysis of poverty and inequality (e.g., the 1989-92 change in family income inequality). Also, as discussed below, they did not control for state fixed effects. Both points suggest that despite the clear strengths in Card and Krueger's (1995) methodology, their findings should be replicated while adjusting for these concerns.

\footnotetext{
${ }^{4}$ Moreover, a greater minimum wage may not benefit poor families if it causes an offsetting reduction in public assistance (Freeman 1996).

${ }^{5}$ Going even further, Bell and Wright (1996) found that the minimum wage rates set by U.K. industry wage coun= cils may have actually reduced wages for low-income workers. In a related finding, Sloane and Theodossiou (1996) suggest that there is significant upward wage mobility over time for low-wage workers.
} 
In this manner, 288 state-level observations from the latter 1980s will be examined in the empirical analysis. Data from the latter 1980s are valuable because of the large increase in U.S. income inequality during the period (e.g., DiNardo, Fortin, and Lemieux 1996). Moreover, state-level data from the latter 1980s have substantial advantages in sorting out the impact of minimum wage hikes. For instance, Welch and Cunningham (1978) noted that high rates of federal minimum wage coverage along with the relatively high federal minimum wage rate empirically swamped any variation in state minimum wage laws in 1970 . This changed in the late 1980s. With the federal minimum wage remaining unchanged at $\$ 3.35$ between 1981 and 1990, 15 states (including Alaska and Hawaii) and the District of Columbia enacted a state minimum wage above the federal rate by 1989. These changes created what David Card (1992) termed "remarkable" variation in minimum wage levels. This cross-state variation in the minimum wage rate formed a unique natural experiment of the effects of minimum wage rates that has not been duplicated before or since. ${ }^{6}$

\section{EMPIRICAL MODEL}

The dependent variables are the 1984-89 poverty rate for persons, the 1989 Gini coefficient of family income inequality, and the 1989 variance of log family income for the 48 contiguous states. ${ }^{7}$ Our primary emphasis will be on the poverty rate specifications because the poverty threshold is adjusted to reflect household size and is more likely to represent a measure of well-being. Conversely, the family inequality measures are not adjusted for family size, which also plagues other minimum wage studies on the wage distribution or on income inequality. However, at least family income inequality focuses on the earnings of the entire family over the course of a year (not just an individual worker's hourly wage), which seems more consistent with the concerns of policy makers. It would be interesting to also consider disaggregated poverty and inequality measures based on race, age, gender, or employment, but such measures are unavailable at the state level.

The 1984-89 period is chosen for the poverty rate regressions because only one contiguous state had a minimum wage above the federal level in 1984 (CT), while 13 states had minimum wage rates above the federal level in $1989 .{ }^{8}$ This yields both time series and cross-sectional variation in minimum wage levels. However, in April 1990, the federal minimum wage increased from $\$ 3.35$ to $\$ 3.80$,

\footnotetext{
${ }^{6}$ For example, after the federal minimum wage was increased to $\$ 4.25$ an hour in 1991 , only four states had a minimum rate above the federal rate. In contrast to this study, many minimum wage studies use time series national-level data, which are hampered by the constraint that the federal minimum wage varies infrequently. This creates significantly less minimum wage variation (e.g., Wellington 1991).

${ }^{7}$ The Gini coefficient falls between zero and one and is positively related to inequality. Both the Gini and variance will be multiplied by 100 in the empirical analysis. Along with being well-known, the Gini and variance were chosen as the two inequality measures because the Gini is sensitive to changes in the middle of the distribution while the variance is sensitive to changes in the tails (Levy and Murnane 1992). Thus, using both measures allows us to examine the robustness of the results. Conversely, Card and Krueger (1995) considered changes in income share ratios (e.g., the 90/10 income share ratio).

${ }^{8}$ The 13 states with their average 1989 minimum wage rates in parentheses are: CA (4.25), CT (4.25), ME (3.75), MA (3.75), MN (3.85), NH (3.65), ND (3.37), OR (3.52), PA (3.67), RI (4.10), VT (3.70), WA (3.85), and WI (3.50). Note that this list contains a mixture of high- and low-wage states, where the highest state minimum wages are 27 percent above the federally mandated rate of $\$ 3.35$.
} 
greatly reducing cross-sectional variation. Likewise, the $1984-89$ period was a period of national economic expansion, while 1990 was the beginning of a national recession, which can confound the estimates. ${ }^{9}$ The state-level family inequality measures are only available for 1989 due to data limitations. Regardless, 1989 has the advantage of having the greatest cross-sectional variation in minimum wage levels.

Our empirical model of regional variations in poverty and income inequality is a standard reduced-form specification that has been used in previous regional-level analysis of the income distribution (e.g., Levernier, Rickman, and Partridge 1995; Levernier, Partridge, and Rickman 1998; Partridge, Rickman, and Levernier 1996). The explanatory factors should be familiar from the recent inequality literature. Specifically, the following equation will be estimated for state $\mathrm{s}$ in year $\mathrm{t}$ :

$$
\begin{aligned}
& \text { OUTCOME }_{s t}=\alpha \mathrm{LMINWAGE}_{\mathrm{st}}+\beta \mathrm{LMINWAGE} \mathrm{COV}_{\mathrm{st}}+\delta \mathrm{INCOME}_{\mathrm{st}}+ \\
& \pi \mathrm{LABOR}_{\mathrm{MKT}}+\Phi \mathrm{DEMOG}_{\mathrm{st}}+\sigma_{\mathrm{s}}+\tau_{\mathrm{t}}+\mathrm{e}_{\mathrm{st}},
\end{aligned}
$$

where OUTCOME is either the state's poverty rate or one of the two inequality measures; LMINWAGE is the log of the maximum of the federal or state minimum wage; LMINWAGE COV is the log of federal minimum wage coverage; INCOME is an income measure; LABOR MKT is a vector of labor market characteristics; DEMOG is a vector of demographic and human capital attributes; $\sigma_{\mathrm{s}}$ is the state or region fixed effect; $\tau$ is the year fixed effect; e is the residual term; $t=1984-89$ in the poverty models and $t=1989$ in the inequality models; and $\alpha, \beta, \delta$, $\pi$, and $\Phi$ are coefficients or coefficient vectors. The data sources are shown in the notes to Tables 2 and 3.

The log of the maximum of the state or federal minimum wage is the minimum wage rate measure. ${ }^{10,11}$ The standard labor market model also suggests that minimum wage legislation does not just influence the labor market through the minimum wage rate, but also through the relative size of the covered and uncovered sectors (Brown, Gilroy, and Kohen 1982; Gramlich 1976). Minimum wage coverage is incomplete due to exemptions for certain industries as well as exemptions for small firms. Coverage varies across states due to different industry mixes and variations in firm size. Thus, minimum wage coverage will be measured by the state's share of its nonsupervisory labor force covered by the federal minimum wage, where directly considering minimum wage coverage represents an extension

\footnotetext{
${ }^{9}$ For example, Deere, Murphy, and Welch's (1995) conclusion that the 1990-91 federal minimum wage hike reduced employment for low-skilled demographic groups has been criticized because they may not have adequately controlled for greater cyclical variability in employment of less-skilled workers (Kuttner 1997). That is, it is possible that declining employment among low-skilled workers in the early 1990s was primarily caused by the recession, not the minimum wage hike. Hence, recessionary effects will not be confounded with the effects of the federal minimum wage hike in our case.

${ }^{10}$ If a state changed its minimum wage in midyear, a weighted annual average of the minimum wage was used. Lags of the state's minimum wage were included in alternative specifications, but were statistically insignificant. ${ }^{11}$ As shown in Card and Krueger (1995, p. 218), it is unnecessary to deflate wages by the price deflator in the current specification (e.g., by the CPI). That is, the sum of the real minimum wage for state $s$ and year $t$ and the year indicator variable is: $\beta \log \left(\mathrm{MINWAGE}_{\mathrm{st}} / \mathrm{CPI}_{\mathrm{t}}\right)+\tau_{\mathrm{t}}^{*}$. This can be rewritten as $\beta \log \left(\mathrm{MINWAGE}_{\mathrm{st}}\right)-\beta \log \left(\mathrm{CPI}_{\mathrm{t}}\right)+\tau^{*}$. Since $C P I_{t}$ does not vary across states, this can be rearranged as: $\beta \log \left(\mathrm{MINWAGE}_{\mathrm{st}}\right)+\tau_{t}$, where $t=\beta \log \left(C P I_{t}\right)+\tau^{*}$.
} 
of this literature. State-level subminimum wage provisions are not controlled for because subminimum wage rates are rarely utilized by employers (Card and Krueger 1995).

Generally, the effect of a greater minimum wage rate and coverage are theoretically ambiguous. For example, greater earnings for low-income workers affected by increases in the minimum wage rate or coverage act to reduce poverty rates and income inequality. However, as noted above, there are offsetting responses such as disemployment effects that can increase poverty rates and income inequality.

Poverty rates and average earnings should be negatively related (at least if there are no dramatic income distribution changes). Thus, we control for the log of real average weekly earnings in the poverty models. Similarly, to account for any relationship between the level of economic development and income inequality (Partridge, Rickman, and Levernier 1996), real per capita personal income is included in the inequality models.

Several labor market variables are included in most specifications. First, labor force participation is incorporated, where greater labor force participation should reduce poverty rates and income inequality by raising the lower tail of the income distribution. Similarly, goods-producing jobs are perceived as providing less-skilled workers with access to higher paying jobs. Hence, the goods-producing share of employment should be negatively related to poverty rates and income inequality. Bartik (1996) contends that economic growth disproportionately benefits lower income groups because these workers are more likely to be unemployed or underemployed. Thus, the model includes the annual percent change in nonfarm employment. Finally, the inequality models include the percent of the state's nonfarm labor force that is unionized. Unionization has been associated with shifting less-skilled workers to the middle of the income distribution (DiNardo, Fortin, and Lemieux 1996), implying that union density should be negatively related to income inequality. ${ }^{12}$

Several demographic and human capital variables are included in the model as additional controls, where their predicted effects should be readily apparent. Both the poverty and inequality models include the percent of femaleheaded families; the percent of the population over the age of 25 with a high school degree, but not a four-year college degree; and the percent of the population over 25 years old who are college graduates. To control for the age structure of families, the poverty rate models include the percent of the population that is under 14 years old, between 15 and 19, and 65 years and over. The racial composition effects are controlled for by the percent of the population that is AfricanAmerican. However, the percent African-American, female-headed families, and educational attainment are interpolated using 1980 and 1990 Census of Population data, suggesting that these demographic results should be cautiously interpreted.

${ }^{12}$ The unionization variable was insignificant when included in the poverty rate equations, while the other coefficients were not affected. 
Finally, the inequality model includes the percent of the population that immigrated internationally in the previous five years. ${ }^{13}$

State (only in the poverty model) or region fixed effects control for unmeasured factors that influence each state's or region's labor market as well as reflecting unmeasured demographic differences. In the poverty model, one primary factor accounted for by the state fixed effects is the possibility that states that raised their minimum wage were systematically different from the other states (e.g., such states had rapid economic growth and lower poverty rates). The year fixed effects (only in the poverty model) account for national economic factors (cyclical or technological change) and demographic trends that have a common effect on poverty rates across all states.

\section{EMPIRICAL RESULTS}

Table 1 shows some descriptive statistics for 1989 regarding differences between states that raised their minimum wage above the federal minimum of $\$ 3.35$ and the states that did not. In 1989, 13 of the contiguous states had a minimum wage above $\$ 3.35$. In these states, the average poverty rate was only 9.3 percent compared to 13.9 percent in the other 35 states, which is a rather striking difference. In fact, the difference is statistically significant at the $1 \%$ level $(t=4.82)$.

TABLE 1

1989 Poverty and Income Distribution Indicators ${ }^{\text {a }}$

\begin{tabular}{lcc}
\hline & $\begin{array}{c}\text { States With Minimum Wage } \\
\text { Above Federal Rate }\end{array}$ & $\begin{array}{c}\text { States With Minimum Wage } \\
\text { No Higher Than Federal Rate }\end{array}$ \\
\hline Poverty Rate (Persons) & 9.3 & 13.9 \\
& $(2.6)$ & $(3.7)$ \\
Family Income Gini Coefficient x 100 & 38.36 & 40.39 \\
& $(1.84)$ & $(2.17)$ \\
Variance of Log Family Income x 100 & 64.8 & 74.9 \\
& $(6.8)$ & $(9.4)$ \\
Total Unemployment Rate & 4.4 & 5.4 \\
& $(0.8)$ & $(1.4)$ \\
$\mathrm{N}$ & 13 & 35
\end{tabular}

${ }^{2}$ Of the 48 contiguous states, 13 had state minimum wage rates above the federal rate of $\$ 3.35$ in 1989.

Similarly, both the Gini family income inequality measure and the variance of log family income were lower in states with higher minimum wage rates, where again the difference is statistically significant $(t=3.23$ and $t=4.10$, respectively). Finally, the average unemployment rate was only 4.4 percent compared to 5.4 percent in the other 35 states $(t=3.08)$. At first glance, the evidence is strongly consistent with the notion that a higher minimum wage is an effective tool for helping lowincome families. Nonetheless, there could be other factors behind these relationships, for which we turn to the regression analysis to sort out the causal effects.

Column (1) of Tables 2 and 3, respectively, presents the (unweighted) descriptive statistics for the variables in the poverty rate and inequality models. ${ }^{13}$ In sensitivity analysis, the age structure and African-American variables were included in the inequality models, but the results were not affected. Thus, they were omitted from the final model. Likewise, recent foreign immigrant share was included in the poverty rate models, but it was insignificant and the other results were substantially unchanged. 
TABLE 2

Poverty Rate Regression Results (t-statistics) $^{\mathrm{a}}$

(1)

(2)

(3)

(4)

(5)

(Means

(std. dev.)

Poverty Rate (Persons)

Log(Min Wage)

Log(Min Wage Coverage)

Labor Force Participation Rate

Log(Real Average Wage)

Goods-Producing Share

Annual \% Chg in Employment

$\%$ Female Head

$\%$ African-American

$\% 12 \leq \mathrm{ED}<16$

$\%$ 4yr College Graduate

Age 14 \& Under

Age 15 to 19

Age 65 and Over

West

Midwest

South

Year Fixed Effects

State Fixed Effects

$\mathrm{R}^{2}$

$\mathrm{N}$
13.5
$(4.4)$

1.22

$(0.03)$

$-0.16$

(0.06)

66.1

(3.8)

2.09

(0.12)

0.24

$(0.05)$

2.95

(2.07)

14.1

(2.6)

9.7

(9.3)

54.5

(4.8)

18.3

(3.5)

0.23

(0.03)

0.08

$(0.01)$

0.13

$(0.02)$

0.23

(0.42)

3.90

(9.10)

(0.43)

3.26

0.33

(0.47)

(8.89)

5.29

(11.18)

$\mathrm{Y}$
$\mathrm{N}$
0.63

288

(0.26)
$-3.34$

(0.87)

28.69

(2.97)

$-0.36$

(3.09)

3.11

(0.66)

$-30.03$

(1.78)

$-0.20$

(1.84)

$-.536$

(1.41)

26.67

(2.76)

$-0.27$

(2.33)

4.00

(0.49)

$-44.96$

(2.54)

$-0.15$

(1.47)

1.72

(1.97)

$-1.10$

(1.16)

$-0.31$

(1.48)

$-0.45$

$(0.58)$

$-6.69$

(1.43)

$-294.4$

(2.44)

$-213.0$

(2.81)

$-5.04$

(1.32)

$-0.25$

(2.25)

1.48

(0.19)

$-38.91$

(2.26)

$-0.17$

(1.65)

1.84

(2.11)

$-1.25$

(1.31)

$-0.36$

(1.75)

$-0.61$

(0.81)

$-7.27$

(1.49)

$-336.61$

(2.81)

$-193.84$

(2.41)

${ }^{\mathrm{a}}$ The descriptive statistics and the regression are unweighted. The t-statistics use the White correction for heteroscedasticity.

Sources: The individual poverty rate is from the U.S. Department of Commerce, Bureau of Census. The minimum wage is the maximum of the state and federal minimum wage where the state minimum wage is from U.S. Department of Labor, Monthly Labor Review, January issues. Minimum wage coverage is from U.S. Department of Labor, Minimum Wage and Maximum Hours Under the Fair Labor Standards Act. Labor force participation is from U.S. Department of Labor, Geographical Profile of Employment and Unemployment. Average private sector hourly wages are from U.S. Department of Labor, Geographical Profile of Employment and Unemployment and Wages and Employment, where the CPI is used as a deflator. Goods-producing share and employment growth are from U.S. Department of Labor, Employment and Earnings, States and Areas. Shares of female-headed families, AfricanAmerican, education between 12 and 16 years, and college graduates are from the 1980 and 1990 Census of Population. The age shares are from U.S. Department of Commerce, Bureau of the Census, Current Population Survey Data. 
TABLE 3

Gini and Variance Regression Results $(\mathrm{t} \text {-statistics })^{\mathrm{a}}$

\begin{tabular}{|c|c|c|c|c|c|c|c|}
\hline & $\begin{array}{c}\text { (1) } \\
\text { (Means } \\
\text { (std. dev.) }\end{array}$ & $\begin{array}{l}\text { (2) } \\
\text { Gini }\end{array}$ & $\begin{array}{l}\text { (3) } \\
\text { Gini }\end{array}$ & $\begin{array}{l}\text { (4) } \\
\text { Gini }\end{array}$ & $\begin{array}{c}(5) \\
\text { Variance }\end{array}$ & $\begin{array}{c}(6) \\
\text { Variance }\end{array}$ & $\begin{array}{c}(7) \\
\text { Variance }\end{array}$ \\
\hline GINI $\times 100$ & $\begin{array}{l}39.8 \\
(2.3)\end{array}$ & & & & & & \\
\hline Variance $\times 100$ & $\begin{array}{l}72.1 \\
(9.8)\end{array}$ & & & & & & \\
\hline Log (Min Wage) & $\begin{array}{c}1.24 \\
(0.06)\end{array}$ & $\begin{array}{l}-2.36 \\
(0.51)\end{array}$ & $\begin{array}{c}4.21 \\
(1.11)\end{array}$ & $\begin{array}{c}1.81 \\
(0.50)\end{array}$ & $\begin{array}{r}-24.26 \\
(1.34)\end{array}$ & $\begin{array}{l}-4.18 \\
(0.25)\end{array}$ & $\begin{array}{r}-10.58 \\
(0.86)\end{array}$ \\
\hline Log(Min Wage Coverage) & $\begin{array}{l}-0.14 \\
(0.03)\end{array}$ & $\begin{array}{l}17.25 \\
(4.02)\end{array}$ & $\begin{array}{l}15.30 \\
(2.81)\end{array}$ & $\begin{array}{c}3.13 \\
(0.53)\end{array}$ & $\begin{array}{c}86.14 \\
(4.11)\end{array}$ & $\begin{array}{l}80.97 \\
(3.06)\end{array}$ & $\begin{array}{l}14.58 \\
(0.67)\end{array}$ \\
\hline Labor Force Participation Rate & $\begin{array}{c}67.1 \\
(3.7)\end{array}$ & $\begin{array}{l}-0.40 \\
(4.03)\end{array}$ & $\begin{array}{l}-0.45 \\
(4.47)\end{array}$ & $\begin{array}{l}-0.29 \\
(3.22)\end{array}$ & $\begin{array}{l}-1.59 \\
(4.14)\end{array}$ & $\begin{array}{l}-1.47 \\
(3.25)\end{array}$ & $\begin{array}{l}-0.75 \\
(2.06)\end{array}$ \\
\hline Real Per Capita Income & $\begin{array}{l}13,423 \\
(2,305)\end{array}$ & & $\begin{array}{l}2.4 \mathrm{E}-4 \\
(1.64)\end{array}$ & $\begin{array}{l}2.0 \mathrm{E}-5 \\
(0.09)\end{array}$ & & $\begin{array}{l}\text { 5.IE-4 } \\
(0.73)\end{array}$ & $\begin{array}{l}-3.3 \mathrm{E}-4 \\
(0.44)\end{array}$ \\
\hline Goods-Producing Share & $\begin{array}{c}0.22 \\
(0.05)\end{array}$ & & $\begin{array}{l}-9.35 \\
(1.98)\end{array}$ & $\begin{array}{c}-10.16 \\
(2.40)\end{array}$ & & $\begin{array}{r}-34.58 \\
(1.71)\end{array}$ & $\begin{array}{r}-43.92 \\
(2.97)\end{array}$ \\
\hline$\%$ Union & $\begin{array}{l}14.5 \\
(5.9)\end{array}$ & & $\begin{array}{l}-0.08 \\
(1.38)\end{array}$ & $\begin{array}{l}-0.07 \\
(1.64)\end{array}$ & & $\begin{array}{l}-0.03 \\
(0.14)\end{array}$ & $\begin{array}{l}-0.02 \\
(0.15)\end{array}$ \\
\hline Annual \%Chg in Employment & $\begin{array}{c}2.76 \\
(1.50)\end{array}$ & & $\begin{array}{c}0.002 \\
(0.01)\end{array}$ & $\begin{array}{c}0.11 \\
(0.89)\end{array}$ & & $\begin{array}{l}-1.45 \\
(1.89)\end{array}$ & $\begin{array}{l}-0.75 \\
(1.45)\end{array}$ \\
\hline$\%$ Female Head & $\begin{array}{l}14.8 \\
(2.7)\end{array}$ & & & $\begin{array}{c}0.29 \\
(2.67)\end{array}$ & & & $\begin{array}{c}1.70 \\
(4.11)\end{array}$ \\
\hline$\% 12 \leq \mathrm{ED}<16$ & $\begin{array}{l}55.8 \\
(4.4)\end{array}$ & & & $\begin{array}{l}-0.15 \\
(2.26)\end{array}$ & & & $\begin{array}{l}-0.76 \\
(2.15)\end{array}$ \\
\hline$\%$ 4yr College Graduater & $\begin{array}{l}19.3 \\
(3.7)\end{array}$ & & & $\begin{array}{l}-0.06 \\
(0.92)\end{array}$ & & & $\begin{array}{l}-0.29 \\
(1.13)\end{array}$ \\
\hline$\%$ Recent Inter. Immigrants & $\begin{array}{c}1.08 \\
(1.12)\end{array}$ & & & $\begin{array}{c}0.38 \\
(1.32)\end{array}$ & & & $\begin{array}{c}1.02 \\
(0.99)\end{array}$ \\
\hline West & $\begin{array}{c}0.23 \\
(0.42)\end{array}$ & & $\begin{array}{c}1.28 \\
(1.45)\end{array}$ & $\begin{array}{c}1.06 \\
(1.54)\end{array}$ & & $\begin{array}{c}7.94 \\
(2.12)\end{array}$ & $\begin{array}{c}7.61 \\
(3.12)\end{array}$ \\
\hline Midwest & $\begin{array}{c}0.25 \\
(0.44)\end{array}$ & & $\begin{array}{c}1.28 \\
(1.64)\end{array}$ & $\begin{array}{c}1.20 \\
(2.38)\end{array}$ & & $\begin{array}{c}6.10 \\
(1.80)\end{array}$ & $\begin{array}{c}6.14 \\
(3.52)\end{array}$ \\
\hline South & $\begin{array}{c}0.33 \\
(0.48)\end{array}$ & & $\begin{array}{c}2.07 \\
(2.28)\end{array}$ & $\begin{array}{c}0.55 \\
(0.80)\end{array}$ & & $\begin{array}{l}11.22 \\
(3.04)\end{array}$ & $\begin{array}{c}3.62 \\
(1.46)\end{array}$ \\
\hline $\begin{array}{l}\text { Constant } \\
\mathrm{R}^{2}\end{array}$ & 0.57 & $\begin{array}{r}71.73 \\
0.71\end{array}$ & $\begin{array}{r}65.38 \\
0.85\end{array}$ & $\begin{array}{r}64.65 \\
0.58\end{array}$ & $\begin{array}{r}221.33 \\
0.69\end{array}$ & $\begin{array}{r}185.82 \\
0.88\end{array}$ & 171.93 \\
\hline $\begin{array}{l}\mathrm{R}^{2} \\
\mathrm{~N}\end{array}$ & 48 & $\begin{array}{l}0.71 \\
48\end{array}$ & 48 & $\begin{array}{l}0.58 \\
48\end{array}$ & 48 & 48 & 48 \\
\hline
\end{tabular}

${ }^{a}$ The descriptive statistics and the regressions are unweighted. The dependent variables are the Gini coefficient of family income scaled up by 100 and the variance of the natural log of family income scaled up by 100 . The $\mathrm{t}$-statistics use the White correction for heteroscedasticity.

Sources: The Gini and variance are from Levernier, Rickman, and Partridge.(1995). Real per capita income uses data from the Department of Commerce, Survey of Current Business deflated by the CPI (1982-84=100). The percent of the nonfarm labor force that is unionized is from U.S. Department of Commerce, Statistical Abstract. The percent of the population that immigrated in the previous five years is from the 1990 Census of Population.

Columns (2)-(5) in Table 2 contain several alternative regression specifications using the 1984-89 state poverty rate as the dependent variable. Column (2) presents a parsimonious specification with only regional fixed effects that most closely reflect the control variables utilized by Card and Krueger (1995) (but this specification has many more observations and they used a different minimum wage measure). Consistent with Card and Krueger (1995), both the state minimum wage rate and minimum wage coverage are negatively related to poverty rates, although the minimum wage rate is statistically insignificant. To be sure, 
omitting the coverage variable did not alter the statistical significance of the minimum wage rate coefficient. Although Card and Krueger (1995) did not consider coverage, these results imply a greater poverty-reducing effect in extending coverage than in increasing the minimum wage rate. Therefore, in a sense, these results are consistent with Card and Krueger's (1995) contention that minimum wage legislation can be used to reduce poverty rates. In addition, the labor force participation rate is negatively related to poverty rates.

One concern with the parsimonious model in column (2) is that it does not fully control for the state's cyclical conditions. For example, Deere, Murphy, and Welch (1995) questioned Card and Krueger's (1995) conclusion that states with a greater share of workers affected by the 1990-91 federal minimum wage hike suffered little if any negative employment consequences. Specifically, Deere, Murphy, and Welch (1995) contended that low-wage states with a greater share of minimum wage workers were predominantly found in the Sunbelt or West. Thus, rapid economic growth in the Sunbelt and the West at the time of the federal minimum wage increase cushioned the blow for minimum wage workers. To account for the possibility that inadequate cyclical controls were behind the results in column (2), the model in column (3) adds three other labor market indicators and it replaces the regional dummies with state fixed effects. In this case, the minimum wage rate coefficient remains insignificant, but the minimum wage coverage variable becomes positive and statistically significant. In fact, the magnitude of the coverage coefficient is quite large, where a 10 percent increase in the coverage rate increases the poverty rate by about 2.9 percent.

There is a possibility that the state fixed effects inadequately account for demographic features of the state, even though the short period under consideration implies that demographic attributes should remain relatively constant. Therefore, the model in column (4) includes several demographic attributes. Given that many of the demographic controls are interpolated, the results in column (4) should be cautiously interpreted. In column (4), coverage remains positively related to poverty rates (with a rather large effect). Likewise, the minimum wage rate coefficient remains negative, but the $t$-statistic rises to 1.41 , which is only statistically significant (two-tail) at the $20 \%$ level (about what Card and Krueger (1995) found). In this case, a 10 percent increase in the state minimum wage rate is associated with a 0.5 percent reduction in the poverty rate.

Finally, to consider whether the minimum wage coverage variable is confounding the minimum wage rate results, the model in column (5) omits the coverage variable. However, the minimum wage rate coefficient is basically unchanged. The overall conclusion is that the minimum wage rate is not significantly related to poverty rates at even the $10 \%$ level (two-tail). Moreover, expanding minimum wage coverage is associated with rather large increases in poverty rates in the more fully specified models. Both of these points suggest that minimum wage legislation is ineffective at lifting lower income households out of poverty. This supports those who contend that minimum wage beneficiaries are 
not necessarily the poor and suggests that better targeted anti-poverty programs would be more effective.

Although the minimum wage appears to be a "blunt instrument" in raising households out of poverty, state minimum wage laws may be enacted to promote a more equitable income distribution. To examine this issue, columns (2)-(4) in Table 3 present three alternative models using the 1989 family Gini coefficient as the dependent variable, while the analogous models in columns (5)-(7) use the variance of the log of family income as the dependent variable. The models in columns (2) and (5) only include the minimum wage variables and labor force participation, which is the closest representation of Card and Krueger's (1995) specifications. Columns (3) and (6) add labor market controls and regional fixed effects. Finally, columns (4) and (7) add demographic controls to the models.

The results show that the minimum wage rate has a statistically insignificant relationship with family income inequality in all six specifications. The minimum wage coverage measure is positively related to income inequality, but this finding is not statistically significant in the more fully specified models in columns (4) and (7). Nonetheless, we find no evidence suggesting that state minimum wage hikes or expanding minimum wage coverage reduce family income inequality, although some caution should be exercised because the model cannot fully account for state fixed effects. ${ }^{14}$ This finding is inconsistent with Card and Krueger's (1995) family income distribution results. However, it should be noted that these results are not necessarily inconsistent with other studies' conclusions that minimum wage hikes reduce wage inequality (e.g., Card and Krueger 1995; DiNardo, Fortin, and Lemieux 1996; Fortin and Lemieux 1997). That is, family income inequality may not fall because of offsetting changes in employment and hours, as well as offsetting changes in labor supply by other family members in response to minimum wage increases (even if wage inequality declines). ${ }^{15}$ Moreover, minimum wage earners are not necessarily members of low-income families.

One implication of these results is that the minimum wage findings are robust for both poverty rates and family income inequality. Another notable result is that labor force participation reduces income inequality, which is consistent with labor force participation being negatively related to poverty rates. Hence, an effective strategy for reducing poverty or family income inequality should include policies that increase labor force participation. One possibility is to expand the earned income tax credit or, alternatively, to adopt welfare reform policies that encourage work and provide effective job training.

\section{CONCLUSION}

This study examined the influence of state-level minimum wage rates on poverty rates and family income inequality. Our methodology utilizes the

${ }^{14}$ Omitting the coverage variable does not change the minimum wage rate result.

${ }^{15}$ Note that findings that minimum wage hikes reduce wage inequality generally do not include the effects of displaced workers who effectively earn zero. If displaced workers were included, the decline in wage inequality may be reversed. 
natural experiment approach of Card and Krueger (1995), but extends their analysis by using greater degrees of freedom and by directly controlling for state fixed effects (at least in the poverty rate models). Moreover, this study advances other minimum wage studies of poverty and family income inequality because most studies generally simulate labor market responses to minimum wage changes. The 1984-89 time period used in this study exploits the tremendous time series and cross-sectional variation in state minimum wage levels during this period.

The overall conclusion is that raising the minimum wage rate is ineffective at reducing both poverty rates and family income inequality, which is inconsistent with Card and Krueger's (1995) findings. Similarly, minimum wage coverage is positively related to poverty rates and, if anything, is positively related to family income inequality. In fact, the overall minimum wage result appears to be more pessimistic than found in studies based on simulated labor market responses (e.g., Even and Macpherson 1996). One implication is that policy makers should forego (substantial) minimum wage hikes and expansion of minimum wage coverage if the primary public policy goal is to improve the well-being of low-income families. Nonetheless, more research is needed regarding the underlying causes of this finding. That is, is it due to disemployment effects for low-income families, or is it primarily caused by minimum wage earners being too dispersed throughout the income distribution?

On a more positive note, greater labor force participation reduced poverty rates and family income inequality. Thus, policies that directly encourage work, such as the earned income tax credit, job training, transportation to work, and day care, should receive more attention by policy makers. In addition, the failure of state minimum wage policies to mitigate poverty and income inequality further stresses the need to increase the human capital of low-skilled workers through effective job training and education. Moreover, the devolution of welfare programs to state and localities strongly indicates that states and localities will have to play a primary role in the formulation of these policy solutions.

\section{REFERENCES}

Bartik, Timothy J. "The Distributional Effects of Local Labor Market Demand and Industrial Mix: Estimates Using Individual Panel Data." Journal of Urban Economics 40 (1996), 150-178.

Bell, David N.F., and Robert E. Wright. "The Impact of Minimum Wages on the Wages of the Low Paid: Evidence from the Wage Boards and Councils." The Economic Journal 106 (1996), 650-656.

Brown, Charles, Curtis Gilroy, and Andrew Kohen. "The Effect of the Minimum Wage on Employment and Unemployment." Journal of Economic Literature 20 (1982), 487-528. 
Burkhauser, Richard V., Kenneth A. Couch, and David C. Wittenburg. "'Who Gets What' from Minimum Wage Hikes: A Re-Estimation of Card and Krueger's Distributional Analysis in Myth and Measurement: The New Economics of the Minimum Wage." Industrial and Labor Relations Review 48 (1996), 547-552.

Card, David. "Using Regional Variation in Wages to Measure the Effects of the Federal Minimum Wage." Industrial and Labor Relations Review 46 (1992), 22-37.

Card, David, and Alan B. Krueger. Myth and Measurement: The New Economics of the Minimum Wage. Princeton, NJ: Princeton University Press, 1995.

Deere, Donald, Kevin M. Murphy, and Finis Welch. “Employment and the 19901991 Minimum Wage Hike." American Economic Review 85 (1995), 232-237. DiNardo, John, Nicole M. Fortin, and Thomas Lemieux. "Labor Market Institutions and the Distribution of Wages, 1973-1992: A Semiparametric Approach." Econometrica 64 (1996), 1001-1044.

DiNardo, John, and Thomas Lemieux. "Diverging Male Wage Inequality in the United States and Canada, 1981-1988: Do Institutions Explain the Difference?" Industrial and Labor Relations Review 50 (1997), 629-651.

Even, William E., and David A. Macpherson. "Consequences of Minimum Wage Indexing." Contemporary Economic Policy 14 (1996), 67-77.

Fortin, Nicole M., and Thomas Lemieux. "Institutional Changes and Rising Wage Inequality: Is There a Linkage." Journal of Economic Perspectives 11 (1997), 97-116.

Freeman, Richard B. "The Minimum Wage as a Redistributive Tool." Economic Journal 106 (1996), 639-649.

Gramlich, Edward M. "Impact of Minimum Wages on Other Wages, Employment, and Family Incomes." Brookings Papers on Economic Activity 2 (1976), 409-451.

Horrigan, Michael W., and Ronald B. Mincy. "The Minimum Wage and Earnings and Income Inequality." In Sheldon Danziger and Peter Gottschalk (eds.) Uneven Tides, Rising Inequality in America. New York: Russell Sage Foundation, 1993.

Kuttner, Robert. "So Much for the Minimum Wage Scare." Business Week, July 21, 1997, 19.

Levernier, William, Mark D. Partridge, and Dan S. Rickman. "Differences in Metropolitan and Nonmetropolitan Family Income Inequality: A Cross County Comparison." Journal of Urban Economics 44 (1998), 272-290.

Levernier, William, Dan S. Rickman, and Mark D. Partridge. "Variation in U.S. State Income Inequality: 1960-1990." International Regional Science Review 18 (1995), 355-378.

Levy, Frank, and Richard J. Murnane. “U.S. Earnings Inequality: A Review of Recent Trends and Proposed Explanations." Journal of Economic Literature 30 (1992), 1333-1381. 
Machin, Stephen, and Alan Manning. "The Effects of Minimum Wages on Wage Dispersion and Employment: Evidence from the U.K. Wage Councils." Industrial and Labor Relations Review 47 (1994), 319-329.

. "Employment and the Introduction of a Minimum Wage in Britain." The Economic Journal 106 (1996), 667-676.

Neumark, David, and William Wascher. "Employment Effects of Minimum and Subminimum Wages: Panel Data on State Minimum Wage Laws." Industrial and Labor Relations Review 46 (1992), 55-81.

Partridge, Mark D., and Jamie S. Partridge. "Do Minimum Wage Hikes Reduce Employment: State-Level Evidence From the Low-Wage Retail Sector." Journal of Labor Research forthcoming.

Partridge, Mark D., Dan S. Rickman, and William Levernier. "Trends in U.S. Income Inequality: Evidence from a Panel of States." The Quarterly Review of Economics and Finance 36 (1996), 17-38.

Reynolds, Alan. "Even in Boom, Minimum Wage Destroys Jobs." Wall Street Journal, August 20, 1997, A14.

Sloane, P.J., and I. Theodossiou. "Earnings Mobility, Family Income, and Low Pay." The Economic Journal 106 (1996), 657-666.

Welch, Finis R., and James Cunningham. "Effects of Minimum Wages on the Level and Age Composition of Youth Employment." Review of Economics and Statistics 60 (1978), 140- 145.

Wellington, Alison J. "The Effects of the Minimum Wage on the Employment Status of Youth." Journal of Human Resources 26 (1991), 27-46.

Williams, Nicolas. "Regional Effects of the Minimum Wage on Teenage Employment." Applied Economics 25 (1993), 1517-1528. 